\title{
COMPETENNCIAS DOCENTES NO ENSINO SUPERIOR: O QUE NOS DIZ A LITERATURA?
}

\begin{abstract}
Resumo
O novo modelo de universidade inspirado nos princípios do espaço europeu de ensino superior pressupõe uma mudança nos papéis do professor, que passa de transmissor a facilitador das aprendizagens, e assumindo o estudante o papel protagonista do processo educativo. Isso requer a incorporação de um enfoque nas competências a desenvolver na formação universitária, ao considerar que levar a cabo um ensino de qualidade implica que os professores no ensino superior devam ter competências pessoais, formativas, investigativas $e$ pedagógicas que lhes permitam desempenhar a função docente de modo eficaz. Assim, este texto tem como objetivo a identificação das competências pedagógicas mais relevantes para favorecer o desenvolvimento de habilidades, valores e aptidões profissionais e pessoais nos estudantes, com o objetivo de que estes possam fazer face às diferentes situações que irão enfrentar no seu futuro trabalho profissional e melhorar a sua empregabilidade no mercado laboral. Para isso realizamos uma revisão de literatura em níveis nacional e internacional para poder planear o desenho de um instrumento em função das competências mais relevantes extraídas desta revisão: 1) conhecer e compreender; 2) saber fazer e 3) saber ser.
\end{abstract}

Palavras chave: Educação Superior. Competências Docentes. Competências Pedagógicas. 